\title{
PENATALAKSANAAN KASUS KANDIDIASIS PSEUDOMEMBRAN AKUT PADA DIABETES MELLITUS
}

\author{
Lidya Astri*, Siti Rusdiana Puspa Dewi** \\ *Program Studi Kedokteran Gigi, Fakultas Kedokteran, Universitas Sriwijaya, \\ Inderalaya, Sumatera Selatan, Indonesia \\ **Departemen Ilmu Penyakit Mulut, Program Studi Kedokteran Gigi, Fakultas Kedokteran, \\ Universitas Sriwijaya, Inderalaya, Sumatera Selatan, Indonesia \\ Korespondensi: Siti Rusdiana, sitirusdiana@fk.unsri.ac.id
}

\begin{abstract}
ABSTRAK
Latar belakang: Kandidasis pseudomembrane akut sering terjadi pada penderita Diabetes Mellitus. Tujuan dari laporan kasus ini adalah untuk membahas manifestasi oral dan penatalaksanaan kandidasis pada penderita diabetes. Laporan kasus: pasien perempuan berusia 56 tahun datang ke Rumah Sakit Moehammad Hoesin dengan keluhan adanya lapisan putih yang tebal pada lidah sejak 2 bulan yang lalu. Lidah terkadang terasa pedih dan pasien tidak pernah membersihkan lidahnya. Pasien memiliki riwayat penyakit Diabetes Mellitus tidak terkontrol yang terdeteksi sejak 6 bulan yang lalu. Dilakukan pemeriksaan penunjang meliputi pemeriksaan mikrobiologi dan pemeriksaan gula darah. Hasil pemeriksaan mikrobiologi menunjukkan Candida albicans $(+)$ dan didiagnosis Pseudomembran Kandidiasis Akut. Hasil pemeriksaan gula darah menunjukkan kadar gula darah sewaktu 306mg/dl, dan HbAlc 7,5\%. Pasien diberikan medikasi berupa Nistatin drop $12 \mathrm{ml}$ dengan instruksi pemakaian $2 \mathrm{ml} 3 \mathrm{x} /$ hari diteteskan ke seluruh bagian dorsum lidah. Betadin kumur 1\% $100 \mathrm{ml}$ juga diberikan dengan instruksi pemakaian 3x/hari $10 \mathrm{ml}$ dengan cara berkumur sehingga cairan berkontak dengan seluruh bagian yang terinfeksi kandida. Pasien juga diberikan instruksi untuk menjaga kebersihan rongga mulut, menggunakan obat teratur, dan kontrol teratur terhadap kondisi sistemiknya. Kesimpulan: penatalaksanaan oral kandidiasis sangat penting diikuti dengan mengontrol kondisi penyakit yang diderita oleh pasien, sehingga diperoleh prognosis perawatan oral yang baik pula.
\end{abstract}

Kata kunci: Diabetes Mellitus, kandidiasis pseudomembran akut, nistatin

\section{ABSTRACT}

Background: acute pseudomembrane candidiasis often occurs in people with Diabetes Mellitus. The aim of this report is to discuss oral manifestations and management of candidiasis in diabetics. Case reports: the patient was 56 years old woman came to Moehammad Hoesin Hospital with complaining of thick white coating on the tongue since 2 months ago. It felt painful and she never cleaned the tongue. Her medical history showed that she was suffered from Diabetes Mellitus since 6 months ago. Microbiological test and the level of glucose in blood were examined. The microbiological test indicated (+) Candida albicans and patient was diagnosed as Acute Pesudomembrane Candidiasis. The blood sugar level was $306 \mathrm{mg} / \mathrm{dl}$, and HbAlc was 7,5\%. The patient had given Nystatin drop $12 \mathrm{ml}$ and instructed to drop $2 \mathrm{ml}$ three times daily on the dorsal surface of the tongue. Betadine gargle $1 \% 100 \mathrm{ml}$ was also given three times daily for $10 \mathrm{ml}$ each so that the liquid contacted with the infected regions. Patients instructed to keep oral hygiene, use medication regularly, and control her systemic condition. Conclusion: the management of oral candidiasis is really important followed by controlling the disease so that the good prognosis of oral care is obtained.

Keywords: Diabetes Mellitus, acute pseudomembrane candidiasis, nystatin

\section{LATAR BELAKANG}

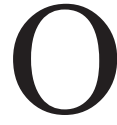
ral candidiasis merupakan penyakit yang sering terjadi pada rongga mulut manusia yang disebabkan oleh pertumbuhan jamur Candida albicans yang berlebihan. ${ }^{1}$ Candida albicans adalah mikroorganisme komensal dan dapat bersifat patogen pada pasien dengan penyakit sistemik, seperti Diabetes Mellitus, pasien dengan imunosupresi khususnya AIDS, pasien yang mengonsumsi kortikosteroid, pasien dengan terapi antibiotik spektrum luas jangka panjang, pasien kelainan darah, dan keganasan. ${ }^{2}$ 
Diabetes melitus (DM) merupakan penyakit metabolik dengan karakteristik berupa hiperglikemia karena terjadi penurunan sekresi insulin, gangguan fungsi insulin, ataupun keduanya. DM dibedakan menjadi dua yakni diabetes melitus tipe 1 (insulin dependent) dan diabetes melitus tipe 2 (non-insulin dependent). Diabetes mellitus tipe 2 merupakan penyakit diabetes dengan prevalensi terbanyak dengan jumlah penderita DM tipe 2 di Indonesia mencapai $90 \%$ dari total jumlah penderita DM yang ada di Indonesia. $^{3}$

Kandidiasis pseudomembran akut adalah salah satu jenis kandidiasis yang paling sering terjadi di rongga mulut dengan tampilan klinis berupa plak putih multipel pada mukosa, dapat dihapus, dan meninggalkan bekas kemerahan/eritema, berdarah, atau nyeri pada mukosa yang berada dibawah daerah yang dihapus. diagnosis banding dari kandidiasis pseudomembran akut yakni leukoplakia dan coated tongue. ${ }^{4}$

Tujuan pembuatan laporan kasus ini yakni untuk memaparkan penatalaksanaan kandidiasis pseudomembran akut pada pasien yang mengalami diabetes melitus yang tidak terkontrol.

\section{LAPORAN KASUS}

Seorang pasien perempuan berusia 56 tahun datang ke poli gigi atas rujukan dari bangsal THT Rumah Sakit Moehammad Hoesin Palembang mengeluhkan adanya lapisan putih tebal pada permukaan lidah yang disadari sejak \pm 2 bulan yang lalu. Lapisan putih tersebut terkadang terasa pedih, sehingga tidak pernah dibersihkan oleh pasien. Berdasarkan anamnesis yang dilakukan, sebelum masuk rumah sakit, pasien mengeluhkan adanya demam, rasa nyeri serta sulit menelan makanan, dan adanya rasa yang mengganjal pada bagian tenggorokan kanan. Pasien dirujuk dari RSUP Musi Banyuasin ke Rumah Sakit Moehammad Hoesin Palembang. Dua hari setelah masuk rumah sakit, dokter spesialis THT merujuk pasien ke bagian poli gigi Rumah Sakit Moehammad Hoesin Palembang untuk dilakukan pemeriksaan.

Pemeriksaan intraoral menunjukkan bahwa pada lidah pasien terdapat lesi plak putih multipel yang tersebar pada $2 / 3$ anterior dorsum lidah, berbatas jelas, dan dapat dihapus, saat dihapus meninggalkan bekas kemerahan. Nilai tingkat kebersihan rongga mulut pasien (OHI-S) yakni 4 dan termasuk dalam ketegori buruk. Eritema dan edema pada gingiva bagian bukal regio a,b,c dan gingiva bagian lingual pada regio d,e,f serta ditemukan sisa akar pada gigi $16,17,18,35,36,37,42$.

Keadaan umum pasien yakni pasien terlihat kurus dan lemah. Pemeriksaan penunjang berupa pemeriksaan gula darah dilakukan dengan nilai glukosa puasa $306 \mathrm{mg} / \mathrm{dl}$ dan $\mathrm{HbAlc}$ 7,5\%. Pemeriksaan ureum dan kreatinin didapatkan hasil $98 \mathrm{mg} / \mathrm{dl} \mathrm{dan} \mathrm{1,66} \mathrm{mg/}$ dl. Swab pada lidah juga dilakukan untuk pemeriksaan mikrobiologi. Gambaran awal lidah pasien terdapat pada Gambar 1.

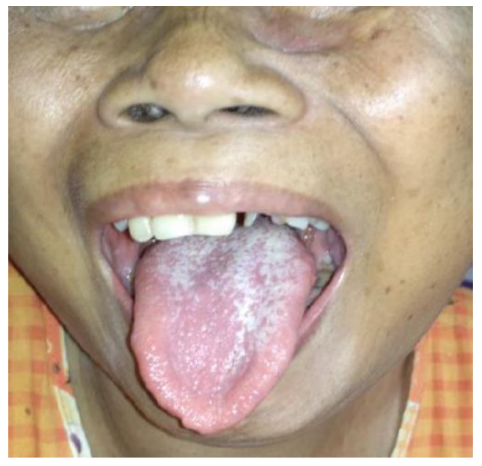

Gambar 1. Kondisi awal lidah pasien, tampak adanya kandidiasis pseudomembran akut pada lidah pasien.

Pemeriksaan penunjang dilakukan untuk membantu menegakkan diagnosis. Hasil dari pemeriksaan mikrobiologi di Rumah Sakit Moehammad Hoesin berupa pemeriksaan kultur jamur dan dijumpai $(+)$ Candida albicans.

Berdasarkan anamnesis, pemeriksaan klinis, dan pemeriksaan penunjang, maka diagnosis dari lesi pada lidah pasien yakni kandidiasis pseudomembran akut et causa diabetes melitus. Pasien diberikan medikasi berupa Nystatin Drop $12 \mathrm{ml}$ dengan instruksi pemakaian $2 \mathrm{ml} \mathrm{3x}$ /hari diteteskan ke seluruh bagian yang terinfeksi kandida (pada dorsum lidah). Betadin kumur $1 \% 100 \mathrm{ml}$ dengan instruksi pemakaian $3 \mathrm{x} /$ hari $10 \mathrm{ml}$ dengan cara berkumur sehingga cairan berkontak dengan seluruh bagian yang terinfeksi kandida yakni dorsum lidah. Pasien juga diberikan instruksi untuk menjaga kebersihan rongga mulut, menggunakan obat yang diberikan oleh dokter umum dan dokter THT secara teratur, dan kontrol teratur.

Satu minggu setelah kunjungan pertama, dilakukan pemeriksaan kembali pada lidah pasien. Lesi plak putih pada dorsum lidah pasien sudah berkurang. Pasien tetap diinstruksikan untuk menjaga kebersihan rongga mulut dan melanjutkan aplikasi obat sesuai dengan instruksi sebelumnya yang telah diberikan dan datang untuk kontrol kembali (Gambar 2).

Pada kontrol kedua, yakni setelah satu minggu kontrol pertama, pasien datang kembali dan dilakukan pemeriksaan obyektif, lesi plak putih pada dorsum lidah mulai berkurang, dan pemeriksaan kultur jamur didapatkan hasil Candida albicans (-). Pasien diinstruksikan untuk tetap menjaga kebersihan rongga mulut dan datang kembali apabila lesi terjadi berulang. Prognosis dari kasus ini baik karena pasien datang kontrol teratur dan menjaga kebersihan rongga mulut. Gambaran klinis lidah pasien pada kontrol pertama dan kedua terdapat pada Gambar 2. 


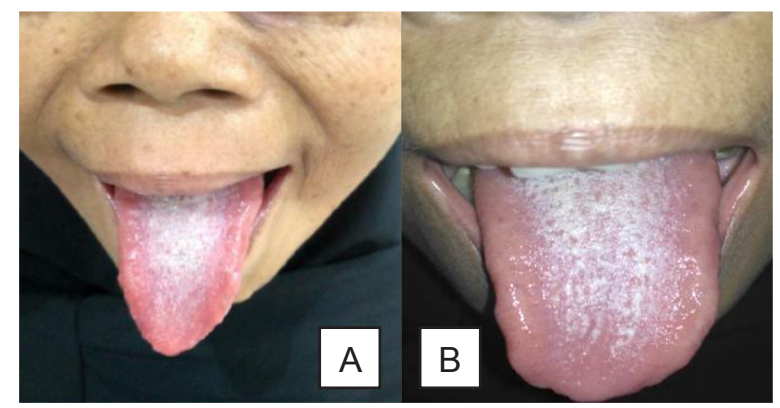

Gambar 2. A) Gambaran klinis dorsum lidah pasien pada kontrol pertama

B) Gambaran klinis dorsum lidah pasien pada kontrol kedua

\section{PEMBAHASAN}

Kandidasis psuedomemnran akut disebabkan oleh jamur Candida albicans yang merupakan mikroorganisme komensal didalam rongga mulut, dan dapat muncul pada keadaan tertentu seperti munculnya penyakit diabetes melitus yang tidak terkontrol. ${ }^{5}$ Diabetes Mellitus menyebabkan pertumbuhan kandida yang cepat. Hal ini berkaitan dengan kadar glukosa yang tinggi dan tidak terkontrol sehingga mengakibatkan kerusakan pada beberapa sel asinar pada kelenjar saliva dan mempengaruhi produksi saliva. ${ }^{6}$ Produksi saliva yang menurun menyebabkan beberapa agen infeksi seperti jamur dapat tumbuh dengan cepat dan menginfeksi mukosa disekitarnya. ${ }^{7}$

Candida albicans menghasilkan enzim ekstraseluler yang dapat merusak struktur host. Salah satu enzim yang penting yakni SAP (Secreted Aspartyl Proteinase). Enzim SAP dapat menghancurkan barier host dengan mendegradasi protein dan diikuti dengan penetrasi lebih dalam ke jaringan. Selain itu, dengan adanya enzim tersebut, kandida dapat menggunakan protein host sebagai sumber nitrogen yang dibutuhkan bagi lingkungan agar tetap dalam kaadaan alkalin sehingga pertumbuhan kandida dapat terus berlangsung. SAP juga dapat menggangu permeabilitas vaskuler sehingga terjadi proses inflamasi dan respon humoral dari host terganggu. ${ }^{8}$

Candida albicans yang diambil dari penderita diabetes memiliki enzim protease, fosfolipase, dan memiliki aktivitas hemolisin. Enzim protease dan fosfolipase memiliki kemampuan dalam menyebabkan patogenesis dari jamur dan banyak dijumpai pada penderita diabetes tipe $2 .{ }^{9}$ Kedua enzim tersebut erusak membran sel, memulai lisis sel, dan kematian sel sehingga penetrasi Candida albicans ke sel host pun dapat terjadi. Hemolisin juga dihasilkan oleh Candida albicans untuk menghancurkan sel darah merah untuk produksi zat besi yang penting untuk perkembangan dan pertahanan hidup dari jamur. ${ }^{10}$ Permukaan sel yang hidrofobik memiliki peran yang sangat penting dalam menyebabkan invasi jaringan fase miselia sel jamur., ${ }^{9,10}$

Diabetes mellitus adalah suatu penyakit kronis yang dapat mengurangi resistensi terhadap infeksi mikroba dan menurunkan kemampuan jaringan dalam memperbaiki strukturnya kembali. ${ }^{7}$ Adanya disfungsi dan metabolisme endokrin yang melibatkan kontrol kadar glukosa darah, menyebabkan terjadinya hiperglikemia. Hiperglikemia kronis dapat memicu gangguan sistem imunoregulasi, sehingga meningkatkan risiko infeksi, karena menurunnya daya kemotaksis, fagositosis, dan mikrobiosidal termasuk di rongga mulut. ${ }^{11}$ Hiperglikemik ini juga memacu kerusakan atau disfungsi dari beberapa organ tubuh, salah satunya adalah kelenjar saliva. ${ }^{12}$

Pertumbuhan Candida albicans sendiri dapat meningkat dengan kaadaan kebersihan rongga mulut yang buruk yang merupakan faktor predisposisi terjadinya kandidiasis pseudomembran akut. ${ }^{13,14}$ Pasien pada laporan kasus ini selain memiliki kelainan sistemik berupa diabetes melitus, pasien juga memiliki kebersihan rongga mulut yang buruk ditandai dengan pemeriksaan OHI-S dengan nilai 4 dan termasuk dalam kategori buruk. Pasien juga mempunyai sisa akar pada gigi 16,17,18,35,36,37,42 .

Kebersihan rongga mulut yang buruk dapat menyebabkan perubahan mikroflora dalam rongga mulut dan jumlah Candida albicans meningkat. Candida albicans pun melakukan invasi ke sel prickel epitel sehingga terjadinya edema interseluler. Sel pun lisis dan terbentuknya ruang pada daerah tersebut. Dikarenakan adanya jumlah Candida albicans yang meningkat, neutrofil menyebar di epitel dan terjadi respon sistem imun disana yang mengakibatkan terjadinya penumpukan hifa, sel deskuamasi, debris, jaringan nekrotik, leukosit dan PMN. Penumpukan tersebut menyebabkan terbentuknya lesi putih berkelompok pada dorsum lidah (kandidiasis pseudomembran akut). ${ }^{10,12,14}$

Terapi yang diberikan pada pasien meliputi terapi dari bangsal THT dan poli gigi Rumah Sakit. Terapi yang diberikan oleh dokter spesialis THT yakni injeksi metronidazole $500 \mathrm{mg}$ setiap 8 jam, injeksi gentamisin $80 \mathrm{mg}$ setiap 12 jam, injeksi metyl prednisolon $62,5 \mathrm{mg}$ setiap 24 jam, dan injeksi ceptazidin $1 \mathrm{~g}$ setiap 12 jam. Pemeriksaan kadar glukosa darah pasien juga dilakukan setiap 6 jam dan diberikan injeksi insulin oleh bagian poli penyakit dalam Rumah Sakit Moehammad Hoesin. Dokter juga meresepkan obat metformin oral $500 \mathrm{mg}$ untuk dikonsumsi pasca pasien dipulangkan dari rawat inap dan diminta untuk kontrol kembali satu minggu setelahnya.

Terapi yang diberikan dari bagian poli gigi adalah Nystatin Drop $12 \mathrm{ml}$ dengan instruksi pemakaian $2 \mathrm{ml} 3 \mathrm{x} /$ hari diteteskan ke seluruh bagian yang terinfeksi kandida (pada dorsum lidah). Betadin kumur 1\% $100 \mathrm{ml}$ dengan instruksi pemakaian 3x/hari $10 \mathrm{ml}$ dengan cara berkumur sehingga cairan berkontak dengan seluruh bagian yang terinfeksi kandida yakni dorsum lidah. Pasien juga diberikan instruksi untuk menjaga kebersihan rongga mulut, menggunakan obat teratur, dan kontrol teratur. 
Perawatan kandidiasis pseudomembran akut dapat mengunakan agen antifungal dan dibagi menjadi tiga kategori utama yakni poliene (nystatin dan amfoterisin B), inhibitor biosintesis ergosterol azole (myconazole, clotrimazole, ketokonazole, itraconazole, dan fluconazole), dan agen-agen baru seperti kaspofungin. Tiga target utama dari agen antifungal yakni sel membran, dinding sel, dan asam nukleat. ${ }^{15}$

Terapi obat yang diberikan pada kasus ini yakni nystatin. Agen antifungal ini merupakan agen antifungal golongan poliene. Nystatin sendiri merupakan salah satu obat yang memiliki efek samping minimal karena nystatin dapat diabsorpsi oleh saluran pencernaan dan tidak memicu resistensi fungal. Mekanisme kerja nystatin yakni mampu berikatan dengan ergosterol yang terdapat pada sel jamur. ${ }^{16}$ Ikatan tersebut menyebabkan integritas membran sel jamur rusak sehingga beberapa bahan intrasel hilang yang mengakibatkan kematian sel jamur. Betadine kumur juga diberikan pada pasien yang merupakan antiseptik yang berperan dalam menjaga kesehatan dan kebersihan rongga mulut dengan efek samping iritasi yang jarang terjadi.

Penanganan keluhan pasien dilakukan oleh dokter dari bagian THT untuk membantu meringankan keluhan utama dibantu oleh dokter gigi, dan dokter bagian penyakit dalam untuk memperbaiki kondisi sistemik pasien yang memicu kandidasis pseudomembran akut. Kontrol gula darah dan konsumsi obat antidiabetes secara rutin tetap harus dilakukan. Kadar glukosa darah yang normal dapat mengembalikan fungsi sistem imunitas tubuh. Disamping itu pola hidup sehat dengan menjaga pola konsumsi dan cara menjaga kebersihan rongga mulut dapat membantu proses penyembuhan dan menguragi rekurensi dari infeksi jamur di rongga mulut.

Berdasarkan anamnesis, pemeriksaan klinis, dan pemeriksaan mikrobiologi dan gula darah puasa, diagnosis dari penyakit pasien yakni kandidasis akut pseudomembran. Pada kontrol pertama, terlihat keluhan subyektif dan lesi plak putih pada dorsum lidah sudah berkurang. Kontrol kedua juga menunjukkan bahwa lesi dalam tahap penyembuhan dan pasien tidak mempunyai keluhan subyektif kembali. Pasien diinstruksikan untuk tetap menjaga kebersihan rongga mulut dan datang kembali apabila lesi terjadi berulang. Prognosis dari kasus ini yakni baik karena pasien datang kontrol teratur dan menjaga kebersihan rongga mulut.

\section{KESIMPULAN DAN SARAN}

Berdasarkan anamnesis, pemeriksaan klinis, dan pemeriksaan penunjang, diagnosis dari kasus ini yakni Pseudomembran Kansisasis Akut, dengan etiologi penyakit sistemik yakni diabetes melitus yang tidak terkontrol dengan faktor predisposisi kebersihan rongga mulut yang buruk. Prognosis perawatan pada kasus ini baik. Keberhasilan perawatan dari kandidiasis pseudomembran akut pada pasien diabetes melitus tergantung pada terapi yang terintegritas antara dokter gigi dan dokter yang menangani penyakit sistemik. Kepatuhan pasien dalam mengikuti instruksi dokter dan kontrol teratur juga berkontribusi dalam keberhasilan perawatan yang dilakukan.

\section{DAFTAR PUSTAKA}

1. Mutiawati VV. Pemeriksaan mikrobiologi pada Candida albicans. Jurnal Kedokteran Syah Kuala 2016; 16 (1): 53-63.

2. Hadiati S. Kandidiasis pseudomembran pada lidah akibat pemakaian obat kumur heksitidin serta penatalaksanaannya. MKGI 2011; 18(2): 178-81

3. Rodrigues CF, Rodrigues ME, Henriques M. Candida sp. Infections in patients with diabetes mellitus. J. Clin. Med. 2019; 8(1): 76.

4. Singh A, Verma R, Murari A, Agrawal A. Oral candidasis: an overview. J. Oral Maxillofac. Pathol. 2014; 18(1): 81-5.

5. Farizal J, Dewa EARS. Identifikasi candida albicans pada wanita penderita Diabetes Mellitus. Jurnal Teknologi Laboratorium 2017; 6(2): 67-74

6. Stewart CR, Obi N, Epane EC, Akba AA, Halpern L, Southerland JH, Gangula PR. The effects of diabetes on salivaru gland protein expression of tetrahydrobiopterin and nitric oxide synthesis and function. J. eriodontol. 2016; 87(6): 735-41

7. American Diabetes Association. Diagnosis and classification of diabetes mellitus. Diabetes Care. 2010; 27(1): 5-10.

8. Castilho DG, Chaves AFA, Navarro MV, Conceicao PM, Ferreira KS, Silva LS, Xander P, Batista WL. Secreted aspartyl proteinase (PbSap) contributes to the virulance of Paracoccidoides brasiliensis infection. Plos One Negl. Trop. Dis. 2018; 12(9): e0006806

9. Gomes CC, Guimaraes LS, Pinto LCC, Camargo GACG, Valente MIB, Sarquis MIM. Investigations of the prevalence and virulance of Candida albicans in periodontal and endodontic lesions in diabetic and normoglycemic patients. J. Appl. Oral Sci. 2017; 25(3): 274-81.

10. Menezes RP, Riceto ABM, Borges AS, Roder DVDB, Pedroso RS. Evaluation of virulence factors of Candida albicans isolated from HIV-positive individuals using HAART. Archiv. Oral Biol. 2016; 66: 61-5

11. Casquerio J, Casquerio J, Alves C. Infections in patients with diabetes mellitus: A review of pathogenesis. Indian J Endocrinol Metab. 2012; 16(1): 27-36.

12. Saskia TI, Mutiara. Infeksi jamur pada penderita diabetes mellitus. Majority 2015; 4(8): 69-74.

13. Vesthi NA, Aditya G, Amalina R. Hubungan kadar urea saliva terhadap derajat keasaman $(\mathrm{pH})$ saliva pada anak usia 12-15 tahun. Odonto J. 2016; 2(2): 57-61.

14. Nur'aeny N, Hidayat W, Dewi TS, Wahyuni IS. Profil oral candidasis di bagian ilmu penyakit mulut RSHS Bandung periode 2010-2014. MKGI 2017; 3(1): 23-8.

15. Patil S, Rao RS, Majumdar B, Anil S. Clinical apprearance of oral candida infection and therapeutic strategies. Front Microbiol. 2015:1-10.

16. Lyu X, Yan Z, Hua H. Efficacy of nystatin for the treatment of Oral candidiasis: a systematic review and meta-analysis. Drug Des Devel Ther. 2016; 10: 1161-71. 